\title{
Virtual Agglomeration of Producer Services and the Changing Geography of Innovation Systems: Implications for Developing Countries
}

\author{
Sheng Liu', Wenjing He², Xiuying Chen ${ }^{3 *}$, Jiayi Xie ${ }^{2}$ \\ ${ }^{1}$ Institute of Studies for the Greater Bay Area, Guangdong University of Foreign Studies, Guangzhou, China \\ ${ }^{2}$ School of Economics and Trade, Guangdong University of Foreign Studies, Guangzhou, China \\ ${ }^{3}$ School of Economics and Trade, Guangdong University of Finance, Guangzhou, China \\ Email: *chenxiuying1128@163.com
}

How to cite this paper: Liu, S., He, W. J., Chen, X. Y., \& Xie, J. Y. (2020). Virtual Agglomeration of Producer Services and the Changing Geography of Innovation Systems: Implications for Developing Countries. Journal of Service Science and Management, 13, 408-419.

https://doi.org/10.4236/jssm.2020.132027

Received: March 31, 2020

Accepted: April 26, 2020

Published: April 29, 2020

Copyright $\odot 2020$ by author(s) and Scientific Research Publishing Inc. This work is licensed under the Creative Commons Attribution International License (CC BY 4.0).

http://creativecommons.org/licenses/by/4.0/

\begin{abstract}
The rapid development of new generation of information and communication technology (ICT) has changed the traditional mode of service spatial configuration. A virtual agglomeration mode of producer service via internet platform is forming and reshaping the spatial organization structure of service industry. Producer services usually show the characteristics of high added value, high knowledge talents and high technology content, which can meet the diversified needs of complex innovation process in the manufacturing industries. Therefore, this paper explores the impact of virtual agglomeration of producer services on the manufacturing enterprises' innovation performance and the changing geography of innovation systems. Compared with the traditional entity agglomeration model, the virtual agglomeration of producer services breaks through the time and space limitations of traditional service provision. It can realize the scale economy effect and knowledge spillover effect in a larger scope, reduce the service input cost, improve the quality of service allocation, and reshape the regional innovation ecosystem. Furthermore, this article conducts a data statistics and a case analysis, and finally puts forward implications for the integration of virtual agglomeration of producer services and manufacturing innovation process especially for enterprises in the developing countries.
\end{abstract}

\section{Keywords}

Producer Services, Innovation Geography, Virtual Agglomeration, Global Value Chain

\section{Introduction}

In recent years, information and communication technology (ICT) has devel- 
oped rapidly, and the internet has provided new opportunities for enterprises, especially in developing countries. In 2015, China lunched the "Internet Plus" action plan, which aims to promote the integration of mobile internet, cloud computing, big data, and the Internet of Things with modern manufacturing to promote the healthy development of e-commerce, industrial internet, and internet finance. The so-called "Internet Plus" is to use ICT and the internet platform to deeply integrate the internet with traditional industries and create new development ecology. In this trend, the mode of industrial agglomeration is no longer restricted to the traditional offline agglomeration. Enterprises can use internet to conduct real-time data exchange and information exchange with upstream and downstream enterprises, and this gradually weakens the geographic connection between enterprises. As supporting service industry directly related to the manufacturing industry, the producer services run through the entire production process of manufacturing enterprises. Under the Internet Plus background, the agglomeration mode of producer services also shows a certain online trend, that is, virtual agglomeration, in order to better serve the production, operation and innovation process of manufacturing enterprises.

At the same time, innovation, as the primary driving force for transition, has an important impact on a country's economy. As an important intermediate input in innovation process, producer services are one of the important means to increase the added value of the product and show the characteristics of high knowledge talents and high technology content. Therefore, the characteristics of producer services will have a certain impact on the innovative behavior of manufacturing enterprises.

In order to give full play to the value of virtual agglomeration of producer services, this article explores the possible impact of virtual agglomeration of producer services on manufacturing enterprise innovation and the evolution of regional innovation ecosystems and describes the possible mechanism. Researches on the theory of agglomeration economy on virtual agglomeration can also be enriched.

The research structure of this paper is as follows. First, the research background and purpose of this paper are introduced. Second, a literature review is conducted, including the concept, evolution, and relationship with manufacturing enterprises of the virtual agglomeration of producer services. Then this paper puts forward the theoretical framework, followed by data statistics and case analysis, and finally provides some suggestions for the integration of virtual agglomeration of producer services and manufacturing innovation process, especially for developing countries.

\section{Literature Review}

\subsection{Concept and Characteristics of Virtual Agglomeration of Producer Services}

Liu et al. (2019) had studied the relationship between the collaborative agglome- 
ration of producer services and the upgrading of manufacturing industry. On this basis, the concept of virtual agglomeration of producer services is extended from the concept of industrial agglomeration. Since Marshall proposed industrial clusters, scholars have subsequently enriched and supplemented this concept. Industrial agglomeration can be defined as a number of different types of enterprises that produce a certain product in a certain region, as well as upstream and downstream enterprises and related service industries supporting these enterprises. With the development of ICT and the gradual popularization of the internet, the links between industries have gradually shifted from offline to online, and the concept of virtual agglomeration has emerged. Brown and Lockett (2001) thought e-clusters are digital enterprise communities which are inter-organizational networks constituted by internet business communities. Passiante, Giuseppina and Secundo, Giustina (2002) considered virtual clusters as unique systems in which suppliers, distributors, service providers, and customers cooperate and compete primarily through the use of "internetworking technologies". Hansen (2004) believes that the digitization of the cluster process has significantly enhanced the competitive advantage of the cluster, and the concept of local or geographical aggregation should be extended to e-cluster. Therefore, the virtual agglomeration of the producer services can be considered as a phenomenon in which producer service enterprises digitize and realize information sharing through the internet, thereby improving their effectiveness and efficiency.

\subsection{Evolution Mechanism of Virtual Agglomeration of Producer Services}

Geographical proximity is not a necessary condition for advanced producer services. Waiengnier et al. (2019) researched the positioning of advanced producer services in the city. They analyzed the local insertion of advanced producer services in the urban area of Brussels according to the dynamic process of local economics and centralization. Using the data of national company register, they found that only some companies are centralized. It can be seen that the influence of geographical factors on the agglomeration of producer services become smaller.

The development of immaterial production and digital technology further promotes the generation of virtual agglomeration. Picard (2008) found that due to the different non-material production needs of the underlying media content, as well as digital production and improved communication systems, media companies were able to create network virtual clusters. Autio et al. (2018) suggested that the entrepreneurial ecosystems are different from traditional clusters. It paid more attention to the development of digital affordances created by digital technologies and infrastructure. Based on this, it proposed a structural model of the entrepreneurial ecosystems in combination with spatial affordances. UlHaq and Schikuta (2010) proposed that in the IT-based service markets, services are combined hierarchically in the form of producers-consumers. The aggrega- 
tion of different levels of service level agreements has brought cross-enterprise business networks, such as virtual enterprise organizations, extended enterprise networks and value networks. These studies show that the intangible production of products and the development of digital technologies have laid the foundation of virtual agglomeration of producer services.

\subsection{Virtual Agglomeration of Producer Services and Manufacturing Enterprises}

With the greenization, servitization and intelligent transformation of industry (Liu et al., 2017; Liu et al., 2018), the input of producer services plays an increasingly prominent role in the innovation process of manufacturing enterprises. Virtual agglomeration can provide a stable environment for the development of a large number of enterprises. Ye and Jiang (2018) used computer simulation to study the entrepreneurial behavior of enterprises in virtual e-commerce cluster. They found that the increasing entrepreneurial enterprises in the cluster are conducive to promote the stability of entrepreneurial enterprises in the entire cluster.

Virtual agglomeration of producer services is conducive to promoting enterprises innovation. Greater innovation in cities stems from a mass of institutions, such as related government agencies and multinational companies (Martinus et al., 2019). Salvador et al. (2013) conducted a research on the "physical" location of the science park and the "virtual" location of innovation cluster. They used a questionnaire to investigate in Piedmont and Italy, and found the two are complementary. They also found that members of innovation cluster highlight the significance of enhancing capabilities and innovation, as well as establishing collaborative research projects.

\subsection{Summary and Comment}

In general, previous literature has been studied the concept and evolution mechanism of virtual agglomeration of producer services, which has laid the foundation for the research of this paper. At the same time, research on the relationship between virtual agglomeration of producer services and enterprises has gradually appeared in the academic world. The methods used to study the relationship between the two are mainly questionnaire surveys and case analysis, and less attention is paid to the mechanism. Therefore, this paper analyzes the mechanism between the virtual agglomeration of producer services and the innovation behavior of manufacturing enterprises, hoping to enrich the relevant research.

\section{Theoretical Framework}

Virtual agglomeration of the producer services can have a positive impact on the manufacturing enterprise innovation through the following two aspects.

First, the virtual agglomeration of the producer services can effectively reduce the transaction costs of innovative activities of manufacturing enterprises. Man- 
ufacturing enterprises need to invest a lot of human, technical and financial resources to carry out innovation activities. In the traditional form, manufacturing enterprises mainly obtain corresponding resources through cooperation with local producer services. With the development of the new generation of ICT, the emergence of the internet has promoted the real-time exchange and sharing of information. The virtual agglomeration of the producer services has effectively integrated resources across regions. The cost of obtaining information and searching for partners has been effectively reduced for manufacturing enterprises. At the same time, manufacturing enterprises can also use the information provided by the virtual agglomeration of producer services to understand consumer needs in a timely manner, which helps manufacturing enterprises to obtain innovation inspiration.

Second, the virtual agglomeration of producer services can increase knowledge spillovers to a certain extent. The virtual agglomeration of the producer services has promoted the exchange of elements and data between the enterprises in the producer services. Through real-time online communication and exchange, the impact of distance has been weakened. The hidden information and knowledge can be easily transferred and learned between enterprises of producer services, forming the first internet knowledge spillover. When online producer services serve manufacturing enterprises through virtual agglomeration, this hidden knowledge will be passed on to the manufacturing enterprises in an invisible form, forming a second internet knowledge spillover. This real-time online network relationship simultaneously promotes the circulation and transfer of explicit and tacit knowledge, increases the knowledge spillover of the internet, and is conducive to the knowledge accumulation of manufacturing enterprises before innovation.

Besides, virtual agglomeration of producer services will also have a positive impact on regional innovation ecosystems. According to the above, it can be known that the virtual agglomeration of producer services can reduce the transaction costs of innovation activities of manufacturing enterprises and increase the knowledge spillover of the internet, which is conducive to the innovation of manufacturing enterprises. In the context of virtual agglomeration of producer services, most of the manufacturing enterprise can enjoy this benefit, which has increased the pressure on manufacturing enterprises in the same region to a certain extent. To gain a competitive advantage, manufacturing enterprises need to continuously innovate, which in turn has promoted the further evolution of local innovation ecosystem.

The complete mechanism is shown in Figure 1.

\section{Specific Application}

\subsection{Data Analysis: Co-Development Status}

\subsubsection{Innovation Status of Manufacturing Enterprises}

As shown in Figure 2, from 2013 to 2017, the number of patent applications by 


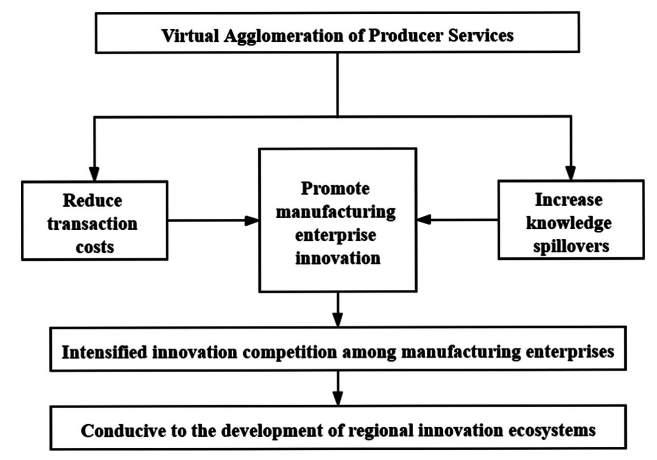

Figure 1. Impact of virtual agglomeration of producer services on manufacturing's innovation.

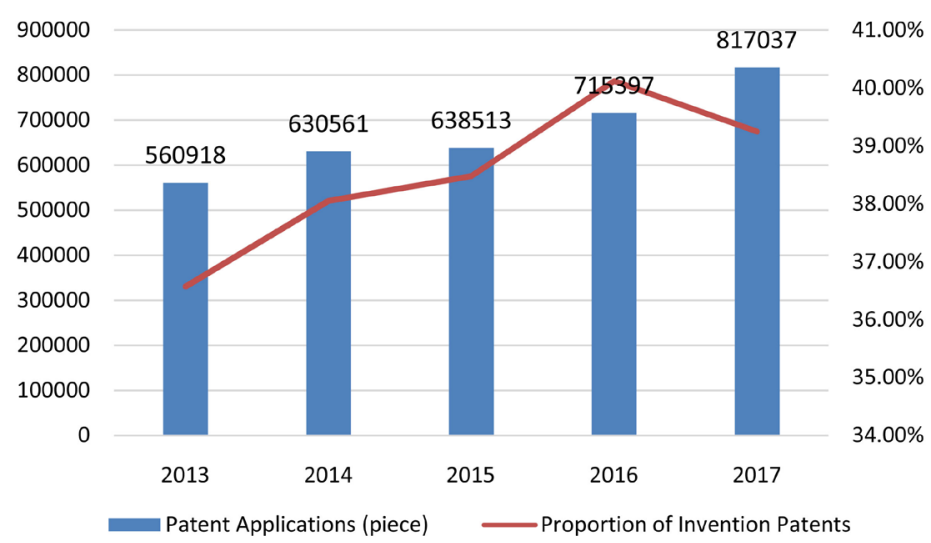

Figure 2. Patent applications of industrial enterprises above designated size in China from 2013 to 2017 (Data resources: China statistical yearbook on science and technology 2018).

industrial enterprises above designated size in China increased year by year, from 560,918 to 817,037 , an increase of $45.66 \%$ over 2013. Among them, the proportion of invention patents also increased from $36.57 \%$ to $39.24 \%$, an increase of nearly 3 percentage points. The number of patent applications can reflect the active level of technological development and the innovation capacity of the society to a certain extent. The increase trend for industrial enterprises above designated size in China reflects the active technological development activities and the enhancement of innovation capabilities.

At the same time, as shown in Figure 3, the sales revenue of new products from industrial enterprises above designated size in China increased from 2013 to 2017 , from 12.85 billion yuan to 19.16 billion yuan, with a growth rate of $49.13 \%$ over 2013. The proportion of revenue from principle business also showed an upward trend, from $12.37 \%$ to $16.91 \%$, an increase of 4.5 percentage points from 2013. New products are the most direct product of innovation and the reaction of innovation activities in the market. The increase in sales revenue of new products reflects to a certain extent the optimization of the supply quality of manufacturing enterprises and the improvement in the quality of economic development. 


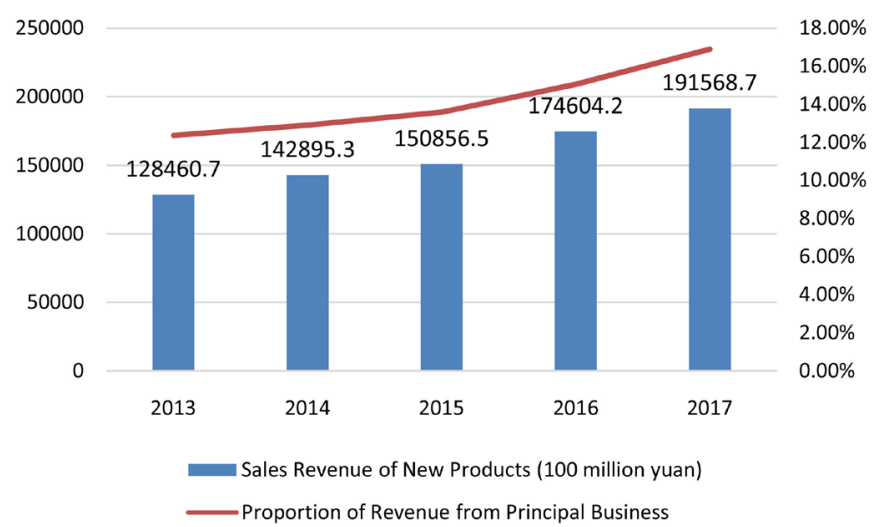

Figure 3. Sales revenue of new product of industrial enterprises above designated size in China from 2013 to 2017 (Data resources: China statistical yearbook on science and technology 2018, China statistic yearbook 2018).

\subsubsection{Status of Virtual Agglomeration of Producer Services}

Producer services can be subdivided into five categories: Traffic, Transport, Storage and Post, Information Transmission, Computer Services and Software, Leasing and Business Services, Scientific Research and Technical Service, Financial Intermediation. It can be seen from Figure 4 that the first four types of producer services that carried out production and operation through the internet from 2013 to 2017 have increased year by year, showing a steady increase trend. Loan service is a basic service of the Financial Intermediation, and its degree of digitization can reflect the integration of the Financial Intermediation and the internet to a certain extent. As can be seen from Figure 5, from 2013 to 2017, the number of online loan platforms also experienced a rapid growth, from 1375 to 6489 , an increase of 3.72 times. This shows that the producer services are actively integrating with the internet, laying the foundation for their virtual agglomeration.

Besides, according to the "Internet Plus" Service White Paper for Small, Medium and Micro Enterprises released by a service providing website in 2018, as shown in Figure 6 and Figure 7, from August 2017 to July 2018, more than half of the top 15 service providers are producer service providers. Among them, brand design service providers ranked first, accounting for nearly $16 \%$. At the same time, the top five service providers with rapid growth also belong to the producer services. It can be seen that the virtual agglomeration of producer services has shown a certain scale on the internet platform and has a good growth rate.

\subsection{Case Analysis: Deloitte's Transition and Online Service Provision}

\subsubsection{Deloitte's Digital Transformation}

Deloitte is one of the representative companies of the knowledge-intensive service industry. Its digital transformation lays the foundation for its participation in the virtual agglomeration of producer services. Its transformation strategy can be divided into two aspects, as shown in Table 1. 


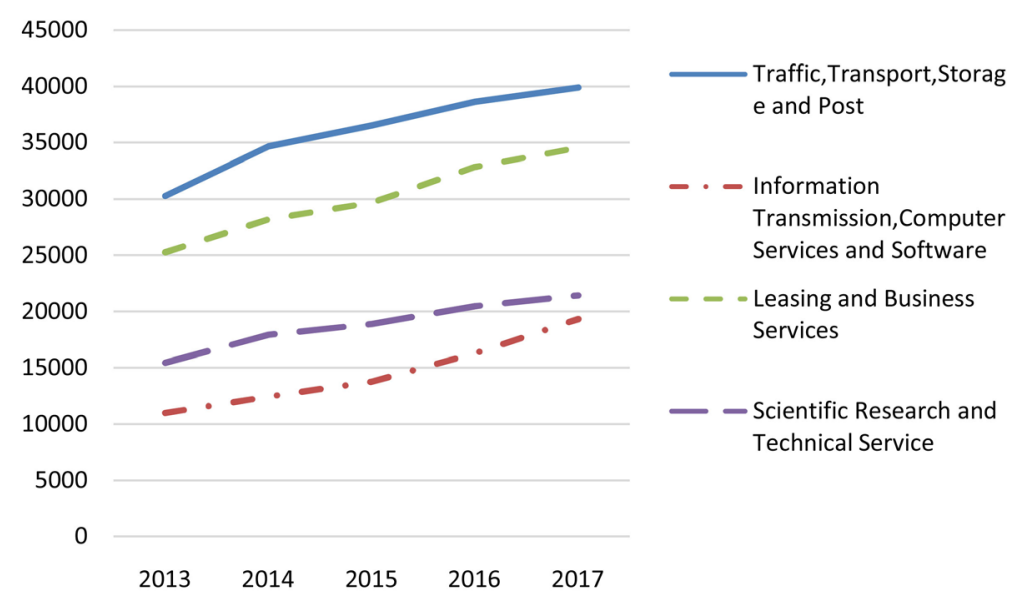

Figure 4. Number of enterprises engaged in production and operation activities via the internet by different types of producer services from 2013 to 2017 (Data resources: China Statistical Yearbook of the Tertiary Industry 2014-2018).

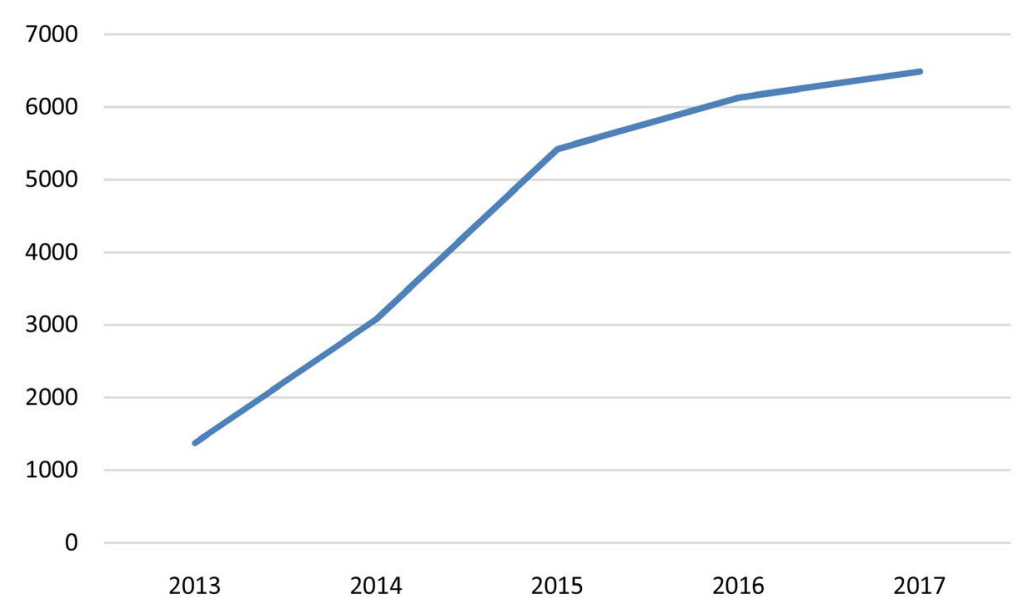

Figure 5. Number of online loan platforms from 2013 to 2017 (Data resources: https://www.p2peye.com/shuju/hysj/ptsl/p2/).

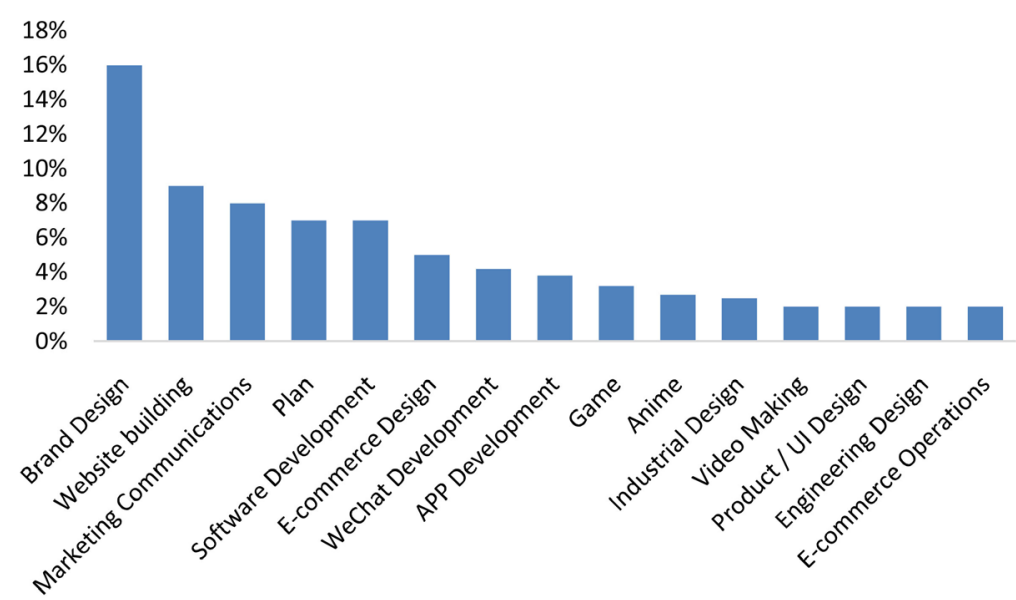

Figure 6. Proportion of service provider category distribution from August 2017 to July 2018 (Data resources:

https://t.cj.sina.com.cn/articles/view/6333658807/17983f6b702700bqq2). 


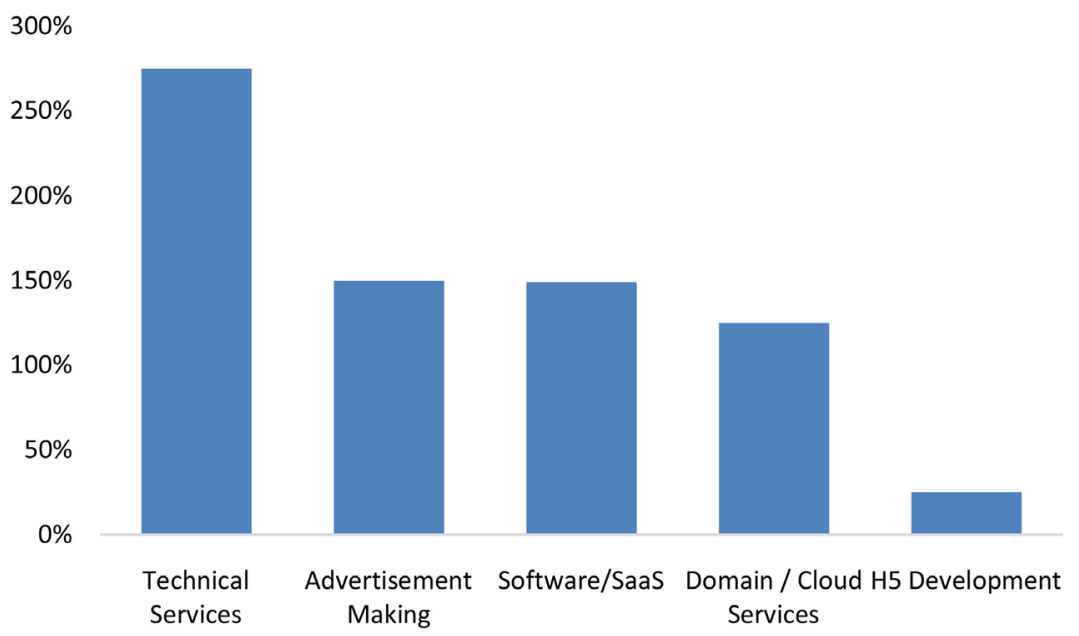

Figure 7. Proportion of service provider category growth from August 2017 to July 2018 (Data resources: https://t.cj.sina.com.cn/articles/view/6333658807/17983f6b702700bqq2).

Table 1. Deloitte digital transformation strategy.

\begin{tabular}{ccc}
\hline Strategy & \multicolumn{2}{c}{ Measures } \\
\hline Deloitte Digital & $\begin{array}{c}\text { Transformation of } \\
\text { business and product }\end{array}$ & Digital business \\
Digital Deloitte & $\begin{array}{c}\text { Transformation of operations } \\
\text { and management }\end{array}$ & Digitizing internal processes \\
& Digital management \\
\hline
\end{tabular}

In terms of Deloitte digitalization, Deloitte first established an exclusive digital brand to provide digital services to corporate users. At the same time, it promotes the digitization of the company's strategic and operational consulting, auditing, tax and other related services, and the IPO service. In addition, Deloitte has also launched the artificial intelligence product "RPA" to automate the audit process.

In terms of digital Deloitte, Deloitte established the Greenhouse, Deloitte China Innovation and Innovation \& Digital Development Center. These departments help Deloitte to accelerate the process of innovation ideas incubation to technology implementation. They can also improve innovation services capabilities of Deloitte. At the same time, more than half of Deloitte's internal processes have been digitized. In terms of management, Deloitte introduced Dcoin and used digital means to build incentives and management for internal employees.

\subsubsection{Online Producer Services for Manufacturing Enterprises' Innovation}

Deloitte helps manufacturing enterprises innovate by providing one-stop, full-service services. Its shared service center applies digital strategies, integrates the resources of manufacturing enterprises with the help of big data, cloud computing, and the internet, and improves the internal and external connectivi- 
ty of manufacturing enterprises. Using this method, it strengthens the information flow between manufacturing enterprises, suppliers and customers. It also helps manufacturing enterprises to realize real-time data accessibility and reduces the cost of information acquisition in the process of manufacturing enterprise innovation. At the same time, relying on its global resources, Deloitte customized market docking services for innovative entrepreneurs. This service helps reduce information asymmetry and solve the problem of linking innovative entrepreneurs and market resources. It also reduces the cost of searching for trading objects during the innovation process to a certain extent. In 2017, Deloitte partnered with the Plug and Play brand to create a new model of platform economic services. This model aims to reduce cultural differences between large and innovative companies, and help both parties effectively identify and collaborate on core needs and share innovation resources. In 2019, Deloitte reached strategic cooperation with domestic and foreign cloud service providers, such as Amazon AWS and Alibaba Cloud, to help manufacturing enterprises to realize business model innovation by achieving digital transformation.

In addition, Deloitte has opened sections such as the "Deloitte Smart Future Research Series" and "Industry 4.0 Center of Excellence" on its online website to share emerging technology knowledge. Manufacturing enterprises can gain access to cutting-edge knowledge by visiting Deloitte's website. They can also use Deloitte's online social platform for further consultation to learn more about innovation.

\subsubsection{Virtual Agglomeration: New Trends and Paths for Developing Countries}

It can be seen that the digitalization of Deloitte has realized the sharing of its resources. Its cooperation with domestic and foreign cloud service providers has proved to a certain extent the phenomenon of virtual agglomeration of the producer services. At the same time, resource sharing helps manufacturing enterprises to reduce transaction costs of innovation and provides an opportunity for them to gain more knowledge. This kind of cooperative behavior between producer services can help the manufacturing enterprises to solve the problem of innovation in the business model of digital transformation. To a certain extent, it proves that the virtual agglomeration of the producer services has a certain positive impact on manufacturing enterprises' innovation.

In terms of the internal conditions of the technological innovation system, the industrial innovation in developing countries started late, and they are still relatively weak in basic research capacity, innovation infrastructure construction, human capital accumulation and innovation incentive mechanism construction, which may further squeeze the development space of the technology front edge in developing countries. Under the new generation of information technology, new technologies, new industries, new business forms and new models have accelerated integration with the real economy. From this point of view, virtual agglomeration of producer services provides developing countries with new op- 
portunities to acquire more cutting-edge knowledge, and provides important support for accelerating technology accumulation and transformation of scientific research achievements.

\section{Conclusion and Discussion}

The rapid development of the internet has broken the geographical limitations and transformed the industry from a traditional geographic cluster to a virtual agglomeration. The virtual agglomeration of the producer services brings a wider range of sharing of information and resources, which reduces transaction costs in the innovation process of manufacturing enterprises and increases knowledge spillover from the internet. In order for manufacturing enterprises to better carry out innovation activities, relevant departments should promote the virtual agglomeration of producer services and encourage manufacturing enterprises to integrate with internet. Therefore, the following suggestions are proposed.

To promote the virtual agglomeration of producer services, the digital transformation of producer services should be promoted. The digitization of producer services is the basis for virtual agglomeration. The digital transformation of producer services should be consistent with the strategic goals of the enterprises. The enterprises should also comprehensively consider the costs and benefits, and choose the appropriate technology to complete the digital transformation. Basic network facilities and the development of network technology should also be promoted. The virtual agglomeration of producer services is based on the internet. The coverage and quality of the internet determine the quality of the virtual agglomeration. Therefore, the government should timely maintain the network infrastructure, invest certain funds in the R \& D of network technology, and promote the further development of network technology.

To encourage the integration of manufacturing enterprises and internet, the government can issue certain policies or provide funds to reduce the cost of using the internet by manufacturing enterprises. At the same time, colleges and universities should attach great importance to the cultivation of students. In the daily teaching process, they should cultivate students' innovative ability, independent thinking ability, logical thinking ability, etc., in order to provide high-quality talents for manufacturing enterprises.

\section{Acknowledgements}

This study was supported by the National Natural Science Foundation of China (71803033), the Humanity and Social Science Youth foundation of Ministry of Education of China (18YJC790101), the Soft Science Project of Guangdong Province (2018A070712034, 2019A101002060), the Natural Science Foundation of Guangdong Province (2019A1515011581), the Project of Philosophy and Social Sciences Planning of Guangzhou in 2020 (2020GZYB42), and the "13th Five Year Plan" of Education Science in Guangdong Province (2019GXJK079). 


\section{Conflicts of Interest}

The authors declare no conflicts of interest regarding the publication of this paper.

\section{References}

Autio, E., Nambisan, S., Thomas, L. D. W., \& Wright, M. (2018). Digital Affordances, Spatial Affordances, and the Genesis of Entrepreneurial Ecosystems. Strategic Entrepreneurship Journal, 12, 72-95. https://doi.org/10.1002/sej.1266

Brown, D. H., \& Lockett, N. J. (2001). Engaging SMEs in E-Commerce: The Role of Intermediaries within eClusters. Electronic Markets, 11, 52-58. https://doi.org/10.1080/10196780151105429

Hansen, U. (2004). E-Clustering: An Innovative Approach for Economic Policy. European Regional Science Association (ERSA). http://hdl.handle.net/10419/117265

Liu, S., Chen, X., Gu, N., \& He, Y. (2019). The Mechanism of the Evolution of Global Value Chain Driven by the Collaborative Agglomeration of Producer Services and Manufacturing Industries. Academic Journal of Business \& Management, 1, 113-119.

Liu, S., Chen, X., Gu, N., \& Tang, X. (2019). The Selection of Spatial Development Mode of Producer Service and Its Spillover Effect on the Manufacturing's Transformation and Upgrading. The Frontiers of Society, Science and Technology, 1, 148-160.

Liu, S., Tao, F., \& Zhang, H. (2017). Term Limits of Public Officials, Environmental Regulations, and Sustainable Development: An Analysis Based on Empirical Spatial Econometrics. Emerging Markets Finance and Trade, 53, 2141-2155. https://doi.org/10.1080/1540496X.2017.1300881

Liu, S., Xia, X. H., Tao, F., \& Chen, X. Y. (2018). Assessing Urban Carbon Emission Efficiency in China: Based on the Global Data Envelopment Analysis. Energy Procedia, 152, 762-767. https://doi.org/10.1016/j.egypro.2018.09.242

Martinus, K., Suzuki, J., \& Bossaghzadeh, S. (2019). Agglomeration Economies, Interregional Commuting and Innovation in the Peripheries. Regional Studies. https://doi.org/10.1080/00343404.2019.1641592

Passiante, G., \& Secundo, G. (2002). From Geographical Innovation Clusters towards Virtual Innovation Clusters: The Innovation Virtual System. European Regional Science Association (ERSA). http://hdl.handle.net/10419/115731

Picard, R. G. (2008). Media Clusters: Local Agglomeration in an Industry Developing Networked Virtual Clusters. JIBS Working Paper Series, No. 2008-3.

Salvador, E., Mariotti, I., \& Conicella, F. (2013). Science Park or Innovation Cluster? Similarities and Differences in Physical and Virtual Firms' Agglomeration Phenomena. International Journal of Entrepreneurial Behavior \& Research, 19, 656-674. https://doi.org/10.1108/IJEBR-10-2012-0108

UlHaq, I., \& Schikuta, E. (2010). Aggregation Patterns of Service Level Agreements. Proceedings of the 8th International Conference on Frontiers of Information Technology, No. 40, 1-6. https://doi.org/10.1145/1943628.1943668

Waiengnier, M., Hamme, G. V., Hendrikse, R., \& Bassens, D. (2019). Metropolitan Geographies of Advanced Producer Services: Centrality and Concentration in Brussels. Tijdschriftvoor Economische en Sociale Geografie, 1-15.

https://doi.org/10.1111/tesg.12394

Ye, Z., \& Jiang, L. (2018). Computer Simulation of the Entrepreneurial Conduction in Virtual E-Business Clusters. EURASIP Journal on Wireless Communications and Networks, 2018, Article No. 89. https://doi.org/10.1186/s13638-018-1118-1 